\title{
Diagnosis of Chronic Prostatitis by Noninvasive Methods in Elderly Patients with Benign Prostatic Hyperplasia in China
}

Research article

Keywords:

Posted Date: December 31st, 2020

DOI: https://doi.org/10.21203/rs.3.rs-108203/v2

License: (c) (1) This work is licensed under a Creative Commons Attribution 4.0 International License.

Read Full License 


\section{Abstract}

The authors have requested that this preprint be withdrawn due to erroneous posting.

\section{Full Text}

The authors have withdrawn this preprint from Research Square. 